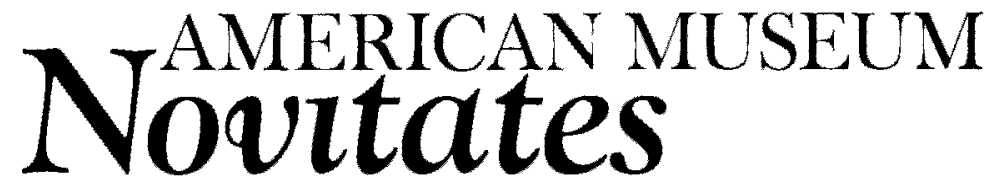

PUBLISHED BY THE AMERICAN MUSEUM OF NATURAL HISTORY CENTRAL PARK WEST AT 79TH STREET, NEW YORK, NY 10024 Number 3541, 16 pp., 9 figures

\title{
Fig Wasps in Dominican Amber (Hymenoptera: Agaonidae)
}

\author{
ENRIQUE PEÑALVER, ${ }^{1,2}$ MICHAEL S. ENGEL, ${ }^{1,3}$ AND DAVID A. GRIMALDI ${ }^{1}$
}

\begin{abstract}
The fauna of fig wasps (Hymenoptera: Chalcidoidea: Agaonidae: Agaoninae) preserved in Early Miocene (Burdigalian) amber from the Dominican Republic is reported. Three species are described, representing both of the exclusively neotropical genera Tetrapus Mayr and Pegoscapus Cameron: Tetrapus delclosi Peñalver and Engel, new species, T. apopnus Peñalver and Engel, new species, and Pegoscapus peritus Peñalver and Engel, new species. All are described and figured based on females that are exquisitely preserved. The species are distinguished from each other as well as from modern relatives.
\end{abstract}

\section{INTRODUCTION}

Among the diverse array of specialized plant-insect interactions, the fig wasps (Agaonidae s.str.: see Rasplus et al., 1998) and the figs (Moraceae: Ficus spp.) they visit are one of the most renowned. The obligate pollination system between these wasps and their fig hosts is remarkably complicated, involving differing breeding systems across the diversity of Ficus species (functionally monoecious versus functionally gynodioe- cious) and varied syndromes in wasp biology and anatomy depending on the host biology (e.g., Ramírez, 1974; Wiebes, 1979; Weiblen, 2002; Cook and Rasplus, 2003; Kjellberg et al., 2005). Recent studies on the phylogeny of the fig wasps indicate that the fig-fig wasp association arose a single time (Machado et al., 1996, 2001; Herre et al., 1996; Rasplus et al., 1998) and may be as old as $75-100 \mathrm{Ma}$ as derived from molecular estimates (Machado et al., 2001; Rønsted et al., 2005). The oldest fossils recognizable as Ficus fruits, however,

\footnotetext{
${ }^{1}$ Division of Invertebrate Zoology, American Museum of Natural History (penalver@amnh.org; grimaldi@amnh.org).

${ }^{2}$ Institut Cavanilles de Biodiversitat i Biologia Evolutiva, Universitat de València, Apt. 2085, E-46071, Valencia, Spain (penalver@uv.es).

${ }^{3}$ Division of Invertebrate Zoology, American Museum of Natural History; Division of Entomology (Paleoentomology), Natural History Museum, and Department of Ecology \& Evolutionary Biology, 1501 Crestline Drive-Suite 140, University of Kansas, Lawrence, Kansas 66049-2811 (msengel@ku.edu).
} 
are from the Eocene of England (Collinson, 1989), from 20-45 Ma younger than the estimates for the origin of the fig-fig wasp mutualism, suggesting rather a Cenozoic diversification of the fig-fig wasp association. Unlike all other specialized, obligate pollination systems where there is no fossil record (e.g., yucca-yucca moths), fig wasps have been discovered as fossils. Indeed, numerous inclusions of fig wasps have been discovered in Dominican amber and, as documented elsewhere (Peñalver et al., in prep.), some are even preserved in association with pollen from their fig hosts. Herein we provide a taxonomic account of this extinct fauna so as to make the names available for a forthcoming study of the paleobiology and paleoecology of fossil Agaoninae. Format for the descriptions generally follows that employed by Wiebes (1995) for New World Agaoninae. Interestingly, in the New World only two genera of agaonines are native, Tetrapus Mayr and Pegoscapus Cameron. The systematics of neither has been intensively studied, although a useful preliminary monographic treatment was published by Wiebes (1995). Not surprisingly, the fossil agaonine fauna in Dominican amber includes representatives of both of these neotropical genera, establishing their native presence since the Miocene.

\section{MATERIAL AND METHODS}

Dominican amber, which is excavated mainly from mines in the mountains north and northeast of Santiago, is a fossil resin originating from an extinct species of Hymenaea tree (Leguminosae: Caesalpinioidea). This amber has been dated as midMiocene (Grimaldi, 1995; Iturralde-Vinent and MacPhee, 1996). All of the agaonid specimens known in Dominican amber are females, an expected outcome, since males are restricted to the cavity of the fig and most of them are apterous.

The material studied herein was acquired through purchase, but authenticity was confirmed in all instances. The pieces were prepared according to the protocol of Nascimbene and Silverstein (2000). Photomicrography employed an Infinity K-2 long-distance microscope and a MicrOptics fiber-optic flash unit (www.microptics.com). The specimens were drawn using a drawing tube attached to a Zeiss microscope. Specimens are housed in the Amber Fossil Collection, Division of Invertebrate Zoology, American Museum of Natural History, New York $(\mathrm{AMNH})$. Unless otherwise indicated, measurements, where provided, are of the holotypes.

\section{SYSTEMATIC PALEONTOLOGY}

\section{Genus Tetrapus Mayr}

Of the three agaonid species in Dominican amber, two belong to the strictly Neotropical and basal genus Tetrapus. Today there are presently recognized seven species of Tetrapus, two of them unnamed (Wiebes, 1995), although this number shall most assuredly rise as the genus is more intensively studied and more thorough collections developed. Among the modern species, Tetrapus costaricanus Grandi (recorded from Mexico, Costa Rica, and Panama) is the only species known in which the female's third antennal article bears an external prominence, or projection. Interestingly, this distinctive trait is shared with the two species described herein from Dominican amber, which is probably a notable apomorphy uniting these species. Intensive cladistic work on New World agaonines is desperately needed as concepts of relationships within each genus are rudimentary.

Within the West Indies today there is documented only $T$. antillarum Ashmead, a species of dubious status and known only from its type material collected on St. Vincent Island (Wiebes, 1995). The fact that the fossil Tetrapus fauna shares putatively derived features with $T$. costaricanus from the Recent of Mesoamerica suggests that the origin of the paleofauna was via dispersal from or direct geological connection with Mesoamerica, followed by later extinction of the insular fauna and a second, later introduction of $T$. antillarum from either South or Central America. Only a new monographic treatment of Tetrapus and cladistic analysis of relationships within the genus (along with a critical test of the monophyly of Tetrapus and Pegoscapus) can further refine potential biogeographic patterns for this group of fig wasps. 
The only fossil record of Tetrapus, indeed the sole description of a fossil fig wasp prior to present study, is a compression of dubious identity from the Eocene-Oligocene shales of Florissant, Colorado: T. mayri Brues (1910). The species was largely placed in Tetrapus based on habitus, and the original description lacks critical details, so the holotype of $T$. mayri should be critically reevaluated. The only other records lack descriptions or formal identifications; these are the figures of Dominican amber agaonines by Poinar (1993), Wu (1997), Poinar and Poinar (1999), and Grimaldi and Engel (2005) (the first of these figuring a Pegoscapus, apparently the new species Pegoscapus peritus, described herein, below; the latter three figuring the new species $T$. delclosi, described herein, below).

The host figs of Tetrapus species belong to Ficus (Pharmacosycea) Section Pharmacosycea. As such, the presence of these fossils in Dominican amber indicates the occurrence of figs of this section in the paleoflora of the Miocene of Hispaniola.

Tetrapus delclosi Peñalver and Engel, new species

figures $1,2 \mathrm{a}, 3 \mathrm{a}, 4 \mathrm{a}, \mathrm{b}$

Agaonidae sp., Wu, 1997: 207 [figured two specimens].

Agaonidae sp., Poinar and Poinar, 1999: 30, 33 [figured, with nematodes].

Agaonidae sp., Grimaldi and Engel, 2005: 423

[figured, with nematodes and pollen grains].

Diagnosis: As previously noted, among living species $T$. delclosi has a similar, albeit slightly larger, process on the third antennal article as that observed in $T$. costaricanus. Tetrapus delclosi differs from $T$. costaricanus by the bidentate mandibular apex (among living species only $T$. ecuadoranus Grandi has a bidentate mandibular apex), the smaller number of outer denticles on the mandibular appendage (6-8 in $T$. delclosi, compared with 15 in $T$. costaricanus), the first protarsomere has 9-13 ventral spines (T. costaricanus and $T$. americanus Mayr have approximately 30 ventral spines, T. mexicanus Grandi has 40, whereas $T$. ecuadoranus has 25), and the slightly more elongate head. Tetrapus delclosi can be distinguished from the only other species of this genus in amber, $T$. apopnus (see below), by the more numerous setae of the distalmost antennal article (fig. 3a), the barrelshaped flagellomeres (fig. 3a; cylindrical in $T$. apopnus, cf. fig. $3 \mathrm{~b}$ ), the smaller number of outer (i.e., lateral) denticles on the mandibular appendage (6-8 in $T$. delclosi; compared with at least 11, perhaps 13, in $T$. apopnus [see below]), smaller number of ventral, or lamellar, serrate ridges (11 in $T$. delclosi, compared with 16 in $T$. apopnus), elongate protibial setae in distal position (versus medial position in $T$. apopnus; cf. fig. 4a, 4c), and differences in the structure of the apical spines of the protibia (cf. figs. $4 \mathrm{~b}$ and $4 \mathrm{c}$, see also Description). Tetrapus delclosi also differs from all other Tetrapus species (living and fossil) in the complete development of the parastigma. In $T$. apopnus and modern species the submarginal vein does not reach the anterior margin of the forewing, usually not turning anterior to form even an incomplete parastigma. In $T$. delclosi the submarginal vein reaches the wing margin but terminates there, thereby creating a complete parastigma, but not forming a marginal vein.

Description: Female. Total body length $1.90 \mathrm{~mm}$, without ovipositor; forewing length $1.62 \mathrm{~mm}$, width $0.68 \mathrm{~mm}$ (as measured in paratype AMNH DR-11-3). Integument faintly imbricate and dark brown. Head slightly longer than wide (length $0.62 \mathrm{~mm}$, width $0.30 \mathrm{~mm}$ ), breadth much greater than compound eye length; gena narrower than compound eye width (figs. 1, 2a). Scape enlarged, rectangular in form, with small external, medial tubercle; third antennal article with prominent external projection bearing a stiff apical seta; fifth to eleventh antennal articles bear one whorl of sensilla lineara, distalmost antennal article with dense setae (fig. 3a); flagellomeres barrel-shaped (fig. 3a). Mandible with two acutely pointed, apical teeth; mandibular appendage with six to eight outer (i.e., lateral) denticles (referred to as "outer row of teeth" by Wiebes, 1995), with 11 ventral serrate ridges (referred to as "inner row of teeth" by Wiebes, 1995); two palplike appendages bearing a single, robust, apical seta anteriorly on labiomaxillary complex (fig. 2a). Profemur distinctly swollen relative to other femora; protibia with two elongate, 

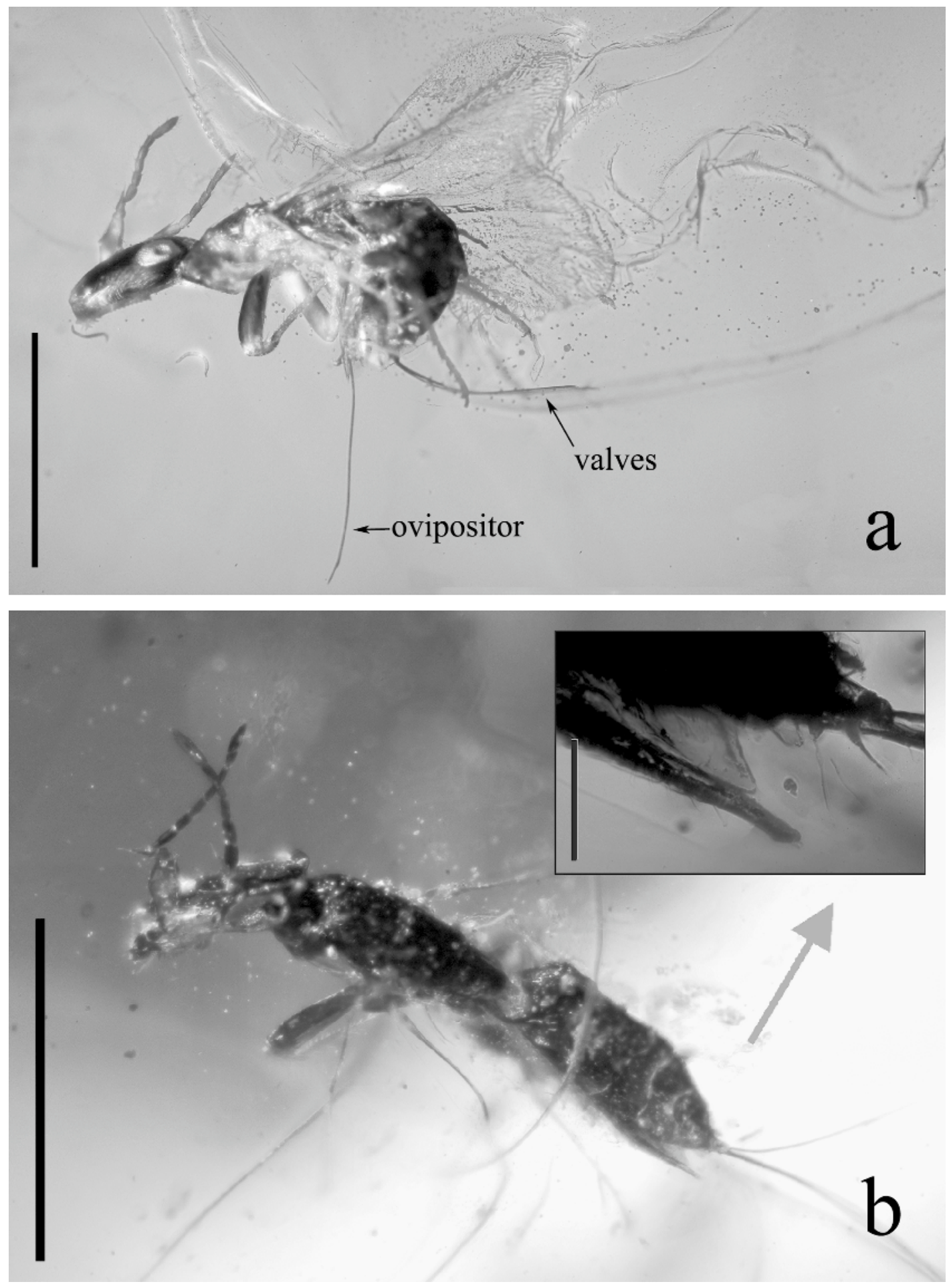
distal setae (fig. 4a, b); protibial apical spines depicted in figure $4 a-b$; outer surface with three spines, two at apex largest and well defined, third in subapical position and somewhat smaller but with well-defined apex; internally with a single, prominent, apical spine and a series of weak, apical knobs along margin; ventral surface of probasitarsus with 9-13 conical spines (fig. 4a); mesosoma slightly longer than metasoma. Venation of forewing reduced, with submarginal vein and parastigma; marginal, postmarginal, and pterostigmal veins absent; various spectral lines in remigium of wing; hind wing with three hamuli. Spiracular peritremata of eighth urotergite prominent and slightly enlarged; protruding terminal, prominent pygostyles (cerci; $0.054 \mathrm{~mm}$ in length), with two apical, elongate setae; external portion of ovipositor $0.86 \mathrm{~mm}$ in length (visible portion $1.06 \mathrm{~mm}$ in length); ovipositor valves slightly longer than metasoma (0.92 $\mathrm{mm}$ in length), without apparent pilosity (fig. 1a). Male. Unknown.

Holotype: Female, AMNH DR-14-576, Early Miocene (Burdigalian) amber from the Dominican Republic. The specimen is associated with fig pollen grains and parasitic nematodes, and all occur in a small, clear piece of amber measuring $15 \mathrm{~mm}$ in length $\times$ $12 \mathrm{~mm}$ in width $\times 5 \mathrm{~mm}$ in depth (thickness). The holotype is in the Amber Fossil Collection, Division of Invertebrate Zoology, American Museum of Natural History.

PARATYPES: Females (three specimens), AMNH DR-11-3 (specimen with fig pollen grains), AMNH DR-14-92 (specimen with fig pollen grains and nematodes, and associated in the same resin flow with two thrips, two chalcidoid wasps, two nematocerans, an immature insect, and vegetal remains), and $\mathrm{AMNH}$ DR-14-710 (specimen with nematodes).

Additional Material: Female, AMNH DR-14-1359. The specimen is poorly preserved and the diagnostic characters of the new species are not easily visible, hence our hesitation to formally designate this individual as a paratype. However, the mandibular appendage is visible laterally and could be satisfactorily reconstructed, suggesting that the specimen is $T$. delclosi.

EтYMOLOGY: The specific epithet is a patronym honoring Dr. Xavier Delclòs, specialist on fossil insects at the University of Barcelona.

\section{Tetrapus apopnus Peñalver and Engel, new species}

figures $2 b, 3 b, 4 c, 5,6$

Diagnosis: Like $T$. delclosi, $T$. apopnus has a slightly larger process on the third antennal article as that in $T$. costaricanus. Tetrapus apopnus can be distinguished from $T$. costaricanus by the more elongate head, which is 2.11 times longer than wide (ca. 1.33 times longer than wide in $T$. costaricanus), and the smaller number of outer denticles and ventral serrate ridges on the mandibular appendage. The species can be distinguished from $T$. delclosi, the only other species of the genus in amber, by the features discussed in the diagnosis for that species (see above).

Description: Female. Total body length $2.06 \mathrm{~mm}$, without ovipositor; forewing length $1.59 \mathrm{~mm}$, width $0.60 \mathrm{~mm}$; hind wing length $0.83 \mathrm{~mm}$, greatest width $0.18 \mathrm{~mm}$. Integument faintly imbricate and dark brown. Head longer than wide (length $0.59 \mathrm{~mm}$, width $0.28 \mathrm{~mm}$ ), breadth much greater than compound eye length; gena narrower than compound eye width (figs. 2b, 5b). Scape enlarged, rectangular in form, with small external, medial tubercle; third antennal article with prominent external projection bearing a stiff apical seta; fifth to eleventh antennal articles bear one whorl of sensilla lineara, distalmost antennal article with sparse setae (figs. 3b, 5b); flagellomeres cylindrical (fig. 3b). Mandible apparently with a single, acutely pointed, apical tooth (difficult to discern in holotype);

Fig. 1. Photomicrographs of Tetrapus delclosi Peñalver and Engel, new species. a. Holotype in lateral view (AMNH DR-14-576); note the trail of fig pollen grains at right (scale bar $=1 \mathrm{~mm}$ ). b. Paratype $($ AMNH DR-14-92) in dorsolateral view (scale bar $=1 \mathrm{~mm}$ ) and detail of the female external genitalia (scale bar $=0.1 \mathrm{~mm})$. 


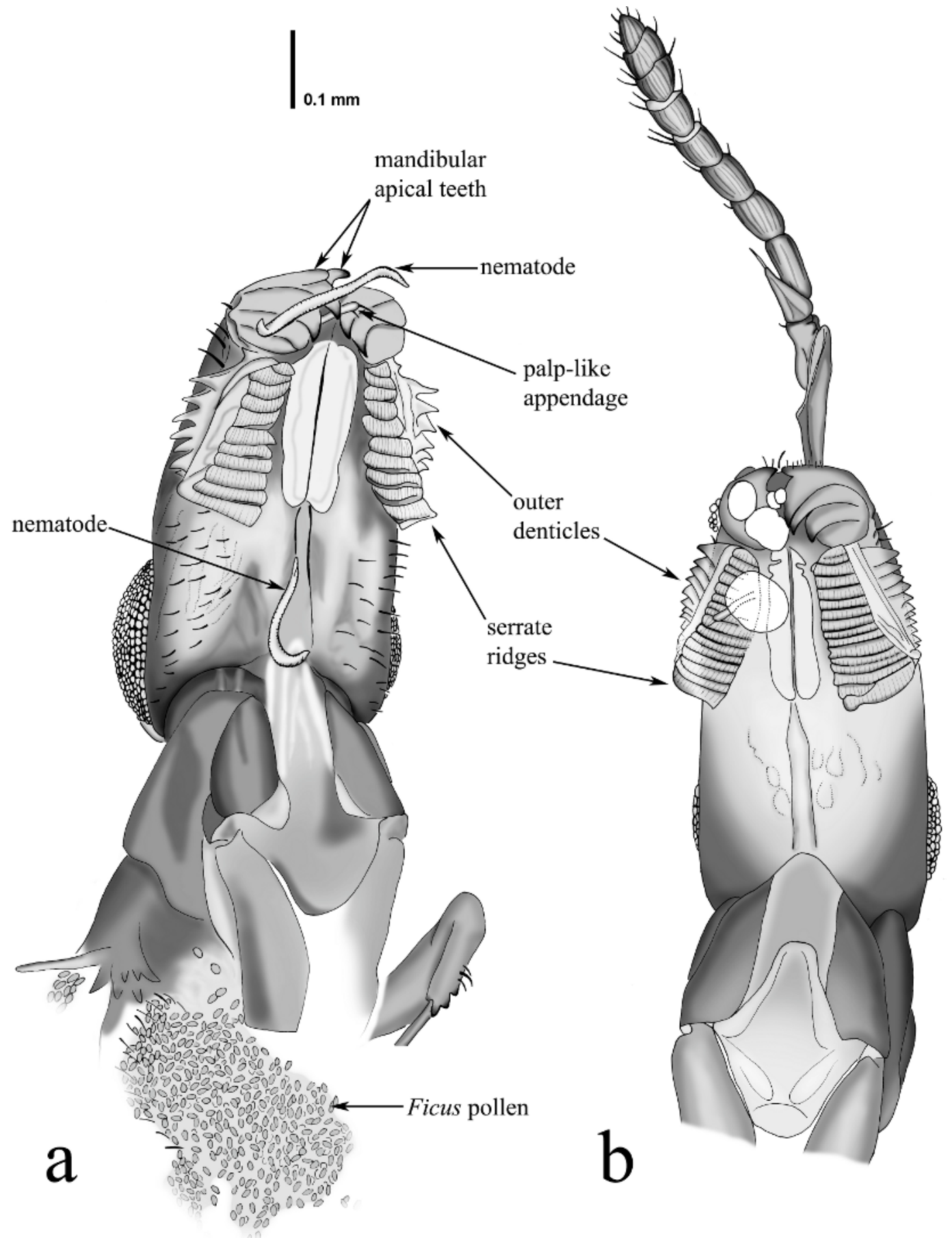

Fig. 2. Camera lucida drawings of the heads in ventral view of the two described species of Tetrapus, for comparison. a. Head of Tetrapus delclosi Peñalver and Engel, new species (holotype: AMNH DR-14-576); note the mass of fig pollen grains under the mesosoma. b. Head of T. apopnus Peñalver and Engel, new species (holotype: AMNH DR-14-282). To the same scale. 

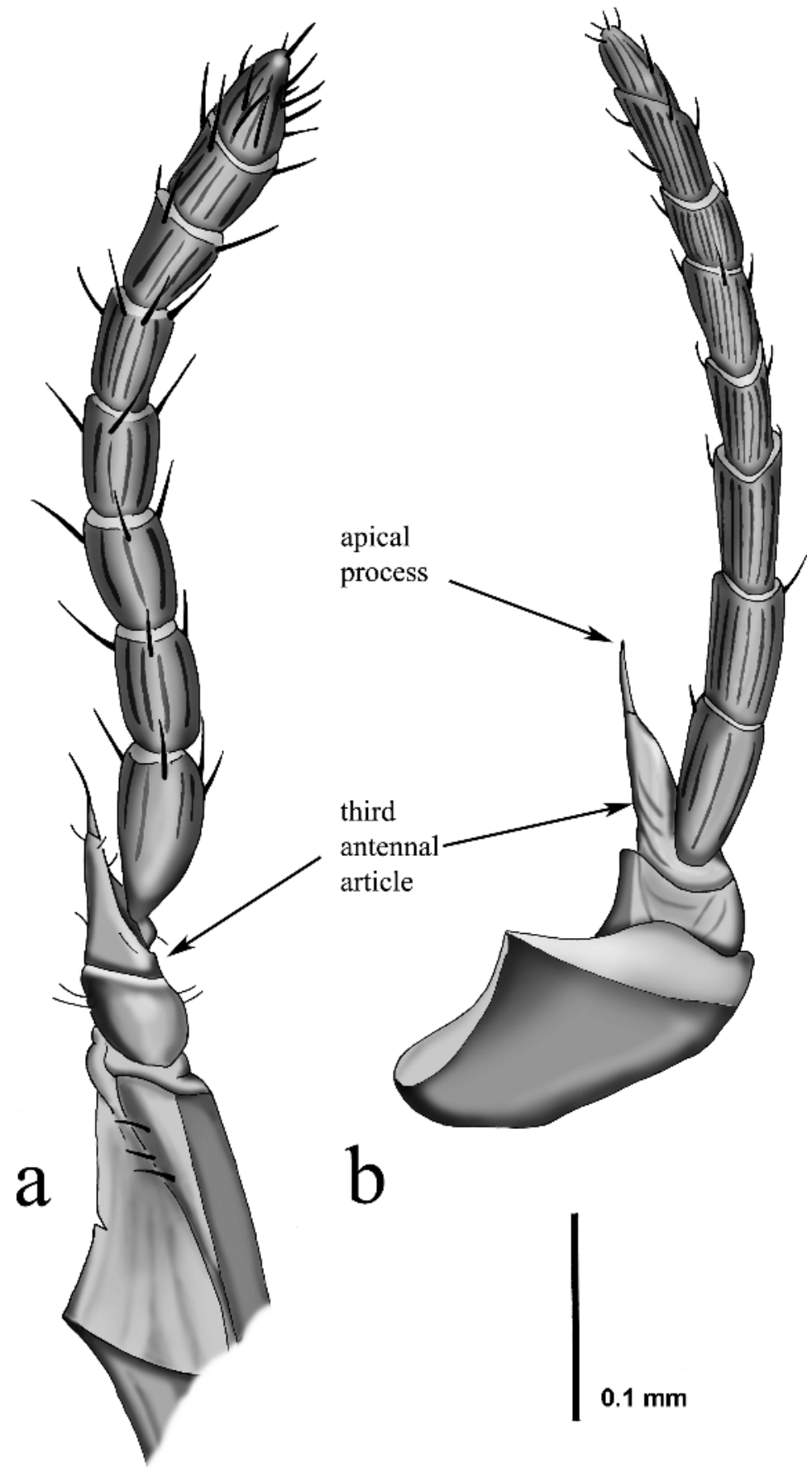

Fig. 3. Camera lucida drawings of the antennae of the two described species of Tetrapus, for comparison. a. Antenna of Tetrapus delclosi Peñalver and Engel, new species (holotype: AMNH DR-14576). b. Antenna of T. apopnus Peñalver and Engel, new species (holotype: AMNH DR-14-282). To the same scale. 


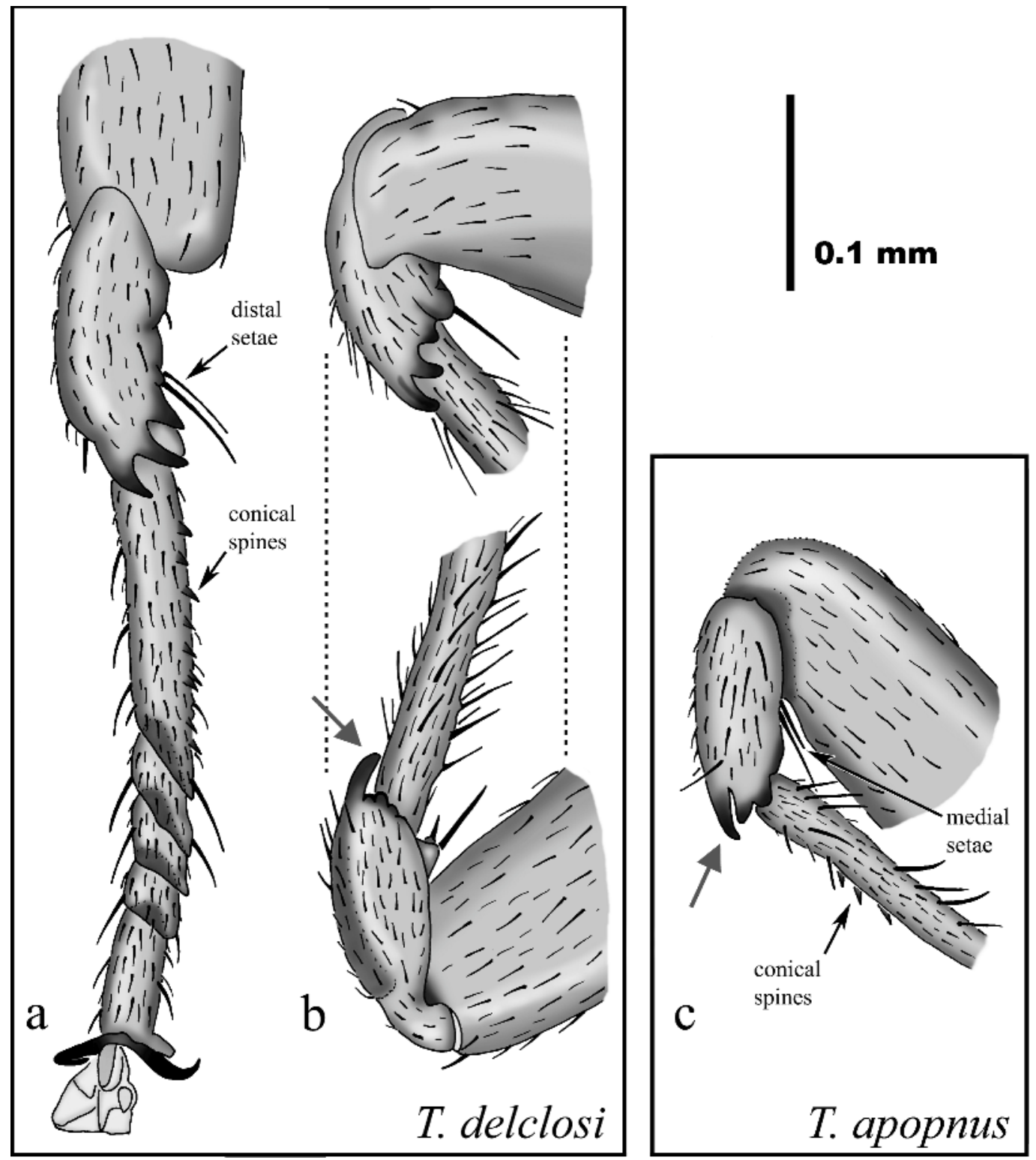

Fig. 4. Camera lucida drawings of the protibiae of the two described species of Tetrapus, for comparison. a. External view of the left foreleg of Tetrapus delclosi Peñalver and Engel, new species (paratype: AMNH DR-11-3). b. Left protibia in external (upper) and internal views (below) of T. delclosi, new species (holotype: AMNH DR-14-576). c. Right protibia of T. apopnus Peñalver and Engel, new species (holotype: AMNH DR-14-282), in internal view. Compare the internal protibial apex with spines of the two species (arrows). All to the same scale.

mandibular appendage with at least 11 easily visible outer (i.e., lateral) denticles, although there appear to be two more for a total of 13 (referred to as "outer row of teeth" by Wiebes, 1995), with 16 ventral serrate ridges (referred to as "inner row of teeth" by Wiebes, 1995) (fig. 2b). Profemur distinctly swollen relative to other femora; protibia with two elongate, medial setae (fig. 4c); protibial apical spines depicted in figure $4 \mathrm{c}$, internally with a single, 

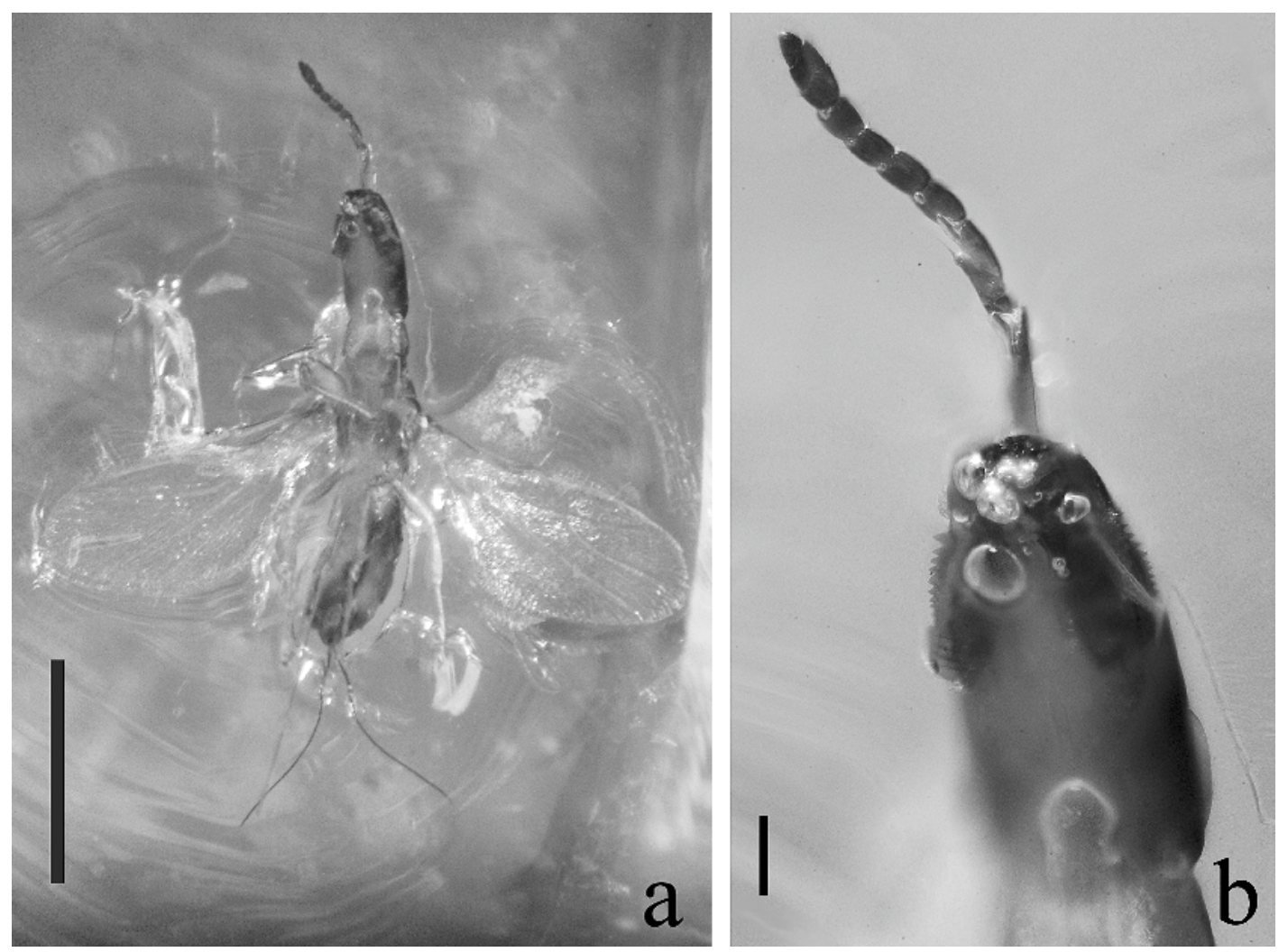

Fig. 5. Photomicrographs of the holotype of Tetrapus apopnus Peñalver and Engel, new species (AMNH DR-14-282). a. Ventral habitus (scale bar $=1 \mathrm{~mm}$ ). b. Ventral view of the head (scale bar $=0.1 \mathrm{~mm}$ ).

prominent, apical spine and two well-produced spines (slightly shorter than apicalmost spine) that are largely fused along their length but with differentiated, blunt apices; ventral surface of probasitarsus with conical spines (number not determinable); mesosoma slightly longer than metasoma. Venation of forewing reduced, with submarginal vein and incomplete parastigma that does not reach wing anterior margin (fig. 6); marginal, postmarginal, and pterostigmal veins absent; various spectral lines in remigium of wing (fig. 6); hind wing with three hamuli. Protruding terminal pygostyles (cerci) absent; external portion of ovipositor $1.07 \mathrm{~mm}$ in length, with two very small apical spines; ovipositor valves slightly longer than metasoma (1.00 mm length), without apparent pilosity (fig. 6). Male. Unknown.

Holotype: Female, AMNH DR-14-282, Early Miocene (Burdigalian) amber from the
Dominican Republic. The specimen is in a small piece of amber, with numerous bubbles and microlayered flows, measuring $13 \mathrm{~mm}$ in length $\times 9 \mathrm{~mm}$ in width $\times 7 \mathrm{~mm}$ in depth (thickness). Syninclusions in the piece include the dehisced wings of a termite (Isoptera) and an entire nematoceran. The holotype, and only known specimen of the species, is in the Amber Fossil Collection, Division of Invertebrate Zoology, American Museum of Natural History.

ETymology: The specific epithet is the Greek word apopnus, meaning "dead".

\section{Genus Pegoscapus Cameron}

Pegoscapus is the more diverse of the two native genera of Neotropical fig wasps. Presently there are 47 recognized species of Pegoscapus, ranging throughout tropical America from Florida and Mexico to 


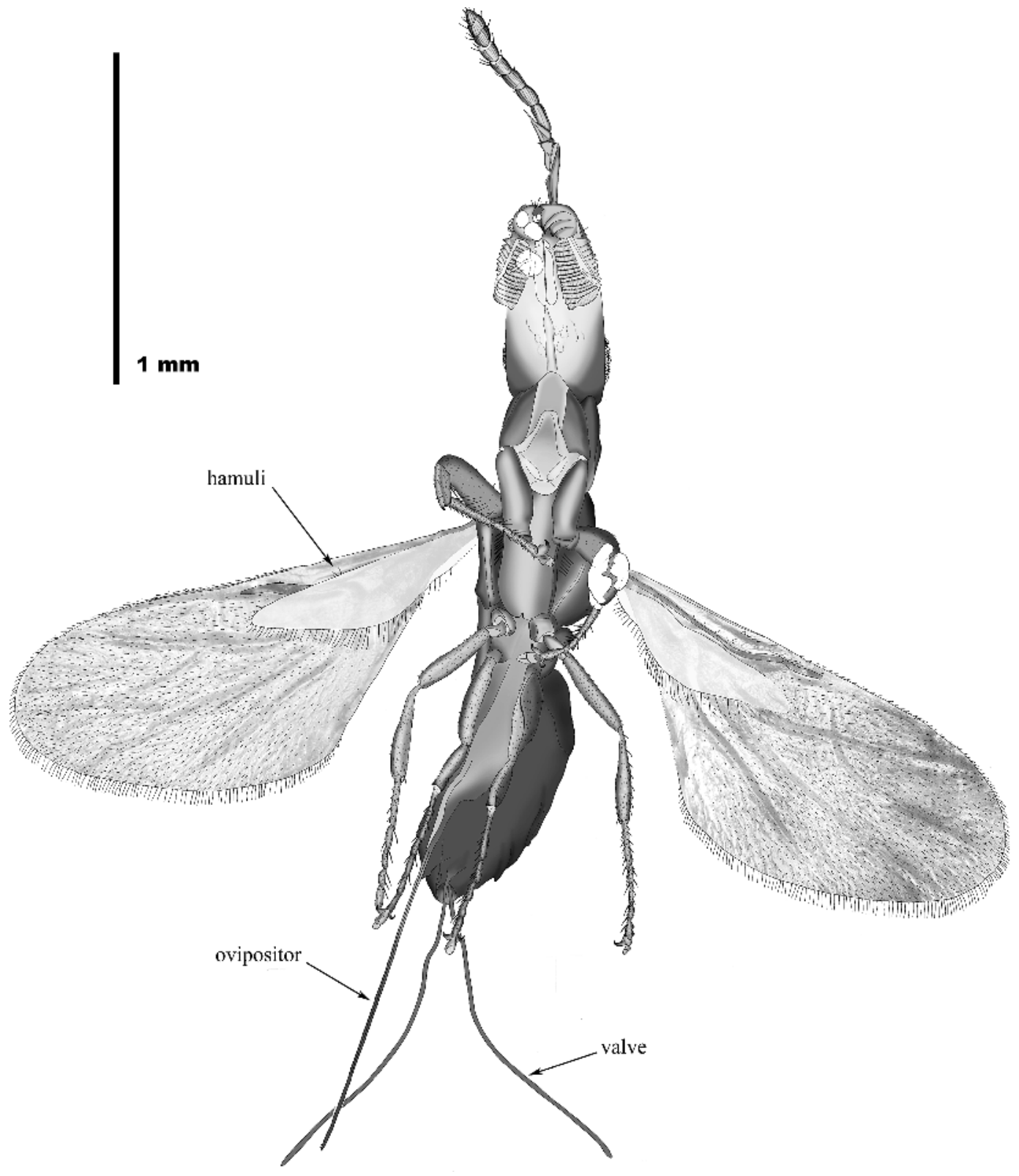

Fig. 6. Camera lucida drawing of the ventral habitus of the holotype of Tetrapus apopnus Peñalver and Engel, new species (AMNH DR-14-282).

Argentina (Wiebes, 1995; Schiffler et al., 2002). Numerous subgenera were recognized within Pegoscapus by Grandi (1919, 1963: as Blastophaga Gravenhorst in an older and much broader sense) but we agree with Wiebes (1995) that a formal subgeneric classification is presently unwarranted and some of these subgroups are now rightly recognized as separate genera (e.g., Jiang et al., 2006). Once a cladistic analysis for Pegoscapus (in the modern, restricted sense) has been completed then the utility of a subgeneric arrangement can be re-evaluated, particularly if subgeneric clades could be 
associated with particular biogeographic regions and/or specific clades or species-groups of host figs. At such time the potential for cocladogenesis between particular groups of Pegoscapus and lineages of Ficus can be critically examined.

The species described herein is easily placed in Pegoscapus as evidenced by the quadrate head that is about as long as wide and the mandibular appendage with a series of ventral lamellae. Despite this, the species has a notable plesiomorphy in the wing venation relative to modern Pegoscapus whereby the postmarginal vein is well developed and distinctly longer than the pterostigmal vein. Whether this indicates that the fossil is sister to modern Pegoscapus requires a detailed analysis of relationships within the genus (as just discussed, above). Another interesting feature for this genus is the segregation of the mandibular lamellae into two, distinct ventral series (one anterior, one posterior and slightly angled relative to the anterior series).

The host figs of Pegoscapus species belong to Ficus (Urostigma) Section Americana. The presence of Pegoscapus in Dominican amber indicates the occurrence of figs of this section in the paleoflora of the Miocene of Hispaniola. Wiebes (1995) provided a summary of the recorded host-wasp species associations for the genus.

\section{Pegoscapus peritus Peñalver and Engel, new species \\ figures 7-9}

Agaonidae sp., Poinar, 1993: 147 [figured], 149. Pegoscapus?, Wiebes, 1995: 8.

Pegoscapus, Machado et al., 2001: 687.

Pegoscapus, Rønsted et al., 2005: 2595.

Diagnosis: The new species can be distinguished from modern relatives by the following combination of features: narrow gena; enlarged, rectangular scape; fifth to eleventh antennal articles without sensilla chaetica, with a single whorl of sensilla lineara; mandibular appendage with twelve ventral lamellae (five in the anterior series, seven in the posterior-angled series: fig. 8); complete forewing venation, with postmarginal vein longer than pterostigmal vein (fig. 9a), a notable plesiomorphy compared to modern Pego- scapus species in which this vein is much shorter than the pterostigmal vein; and short ovipositor valves that are about as long as the metasoma.

Description: Female. Total body length $1.21 \mathrm{~mm}$, without ovipositor; forewing length $0.84 \mathrm{~mm}$, width $0.39 \mathrm{~mm}$, hind wing length $0.46 \mathrm{~mm}$, greatest width $0.08 \mathrm{~mm}$ (all wing metrics from paratype AMNH DR-14-1087a). Integument faintly imbricate and reddish brown (fig. 7). Head about as long as wide (length $0.31 \mathrm{~mm}$, width $0.29 \mathrm{~mm}$ ), breadth much greater than compound eye length; compound eye slightly longer than one-half head length (length $0.16 \mathrm{~mm}$, width $0.08 \mathrm{~mm}$ ); gena narrower than compound eye width (fig. 8). Scape enlarged, rectangular in form; third antennal article with prominent external projection; fifth to eleventh antennal articles bear one whorl of sensilla, without elongate sensilla chaetica. Mandibular appendage with twelve ventral lamellae, five in anterior series, seven in posterior, angled series (fig. 8). Pronotum relatively elongate, slightly shorter than head length (compared to only about one-half of head length in modern species); femora swollen, those of prothoracic segment largest; mesosoma about as long as metasoma. Venation of forewing complete, with submarginal, marginal, postmarginal, and pterostigmal veins, with various spectral lines in remigium of wing; marginal vein short, slightly shorter than pterostigmal vein and parastigma; postmarginal vein well developed, longer than pterostigmal vein (fig. 9a); weak uncus present (fig. 9a); hind wing with three hamuli. Metasoma strongly flattened dorsoventrally, with sternites weakly sclerotized; protruding terminal, prominent pygostyles (cerci; $0.028 \mathrm{~mm}$ in length), with three apical and one subapical, elongate setae (up to 1.5 times length of pygostyle); external portion of ovipositor $0.58 \mathrm{~mm}$ in length; ovipositor valves about as long as metasoma $(0.40 \mathrm{~mm}$ in length), broader distally, and with a ventral row of elongate setae along entire length (fig. 9b). Male. Unknown.

Holotype: Female, AMNH DR-14-1422, Early Miocene (Burdigalian) amber from the Dominican Republic. The specimen is associated with fig pollen grains and phoretic mites or triungula. All occur in a small, clear piece 

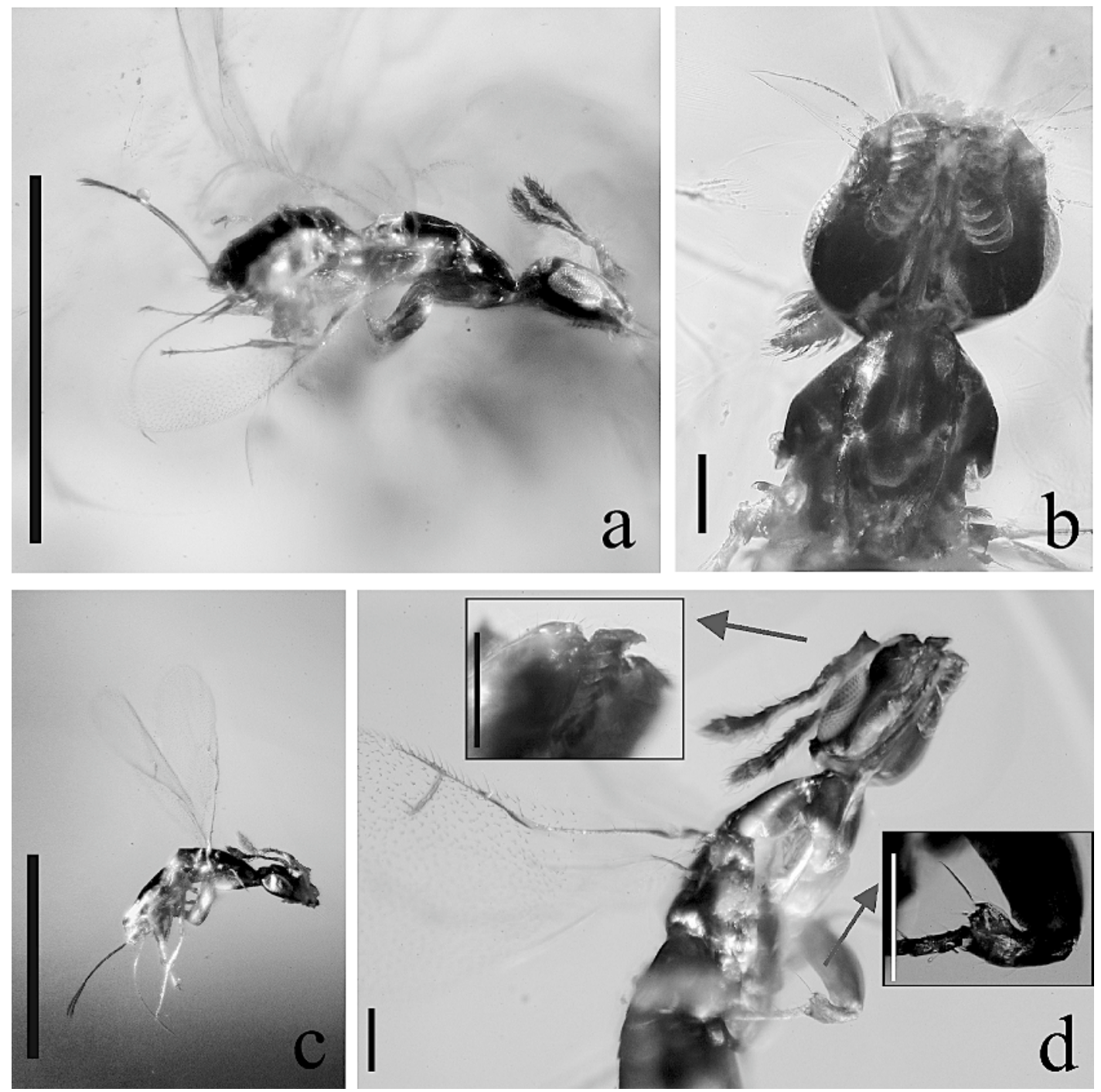

Fig. 7. Photomicrographs of Pegoscapus peritus Peñalver and Engel, new species. a. Lateral habitus of the holotype (AMNH DR-14-1422). (scale bar = $1 \mathrm{~mm}$ ). b. Ventral view of the head of the holotype (scale bar $=0.1 \mathrm{~mm})$. . Lateral habitus of paratype $($ AMNH DR-19-368) $($ scale bar $=1 \mathrm{~mm})$. d. Lateral view of the head and mesosoma of paratype (AMNH DR-14-1087a) (scale bars $=0.1 \mathrm{~mm}$ ).

of amber, with numerous large bubbles, measuring $6 \mathrm{~mm}$ in length $\times 4 \mathrm{~mm}$ in width $\times 3 \mathrm{~mm}$ in depth (thickness). The holotype is in the Amber Fossil Collection, Division of Invertebrate Zoology, American Museum of Natural History.

PARATYPES: Females (11 specimens), AMNH DR-14-184, AMNH DR-14-328 (associated with an anther in the same resin flow and with a chalcidoid wasp), AMNH DR-14- 570a-b-c (three specimens present in the same amber piece as syninclusions, two of them with fig pollen grains), AMNH DR-14-708 (specimen with fig pollen grains), AMNH DR-14-1087a (associated with another agaonid, two nematocerans, and a male spider as syninclusions), AMNH DR-14-1199 (associated with a spider as syninclusion), AMNH DR-14-1256 (agaonid with fig pollen grains and associated with a nematoceran as synin- 

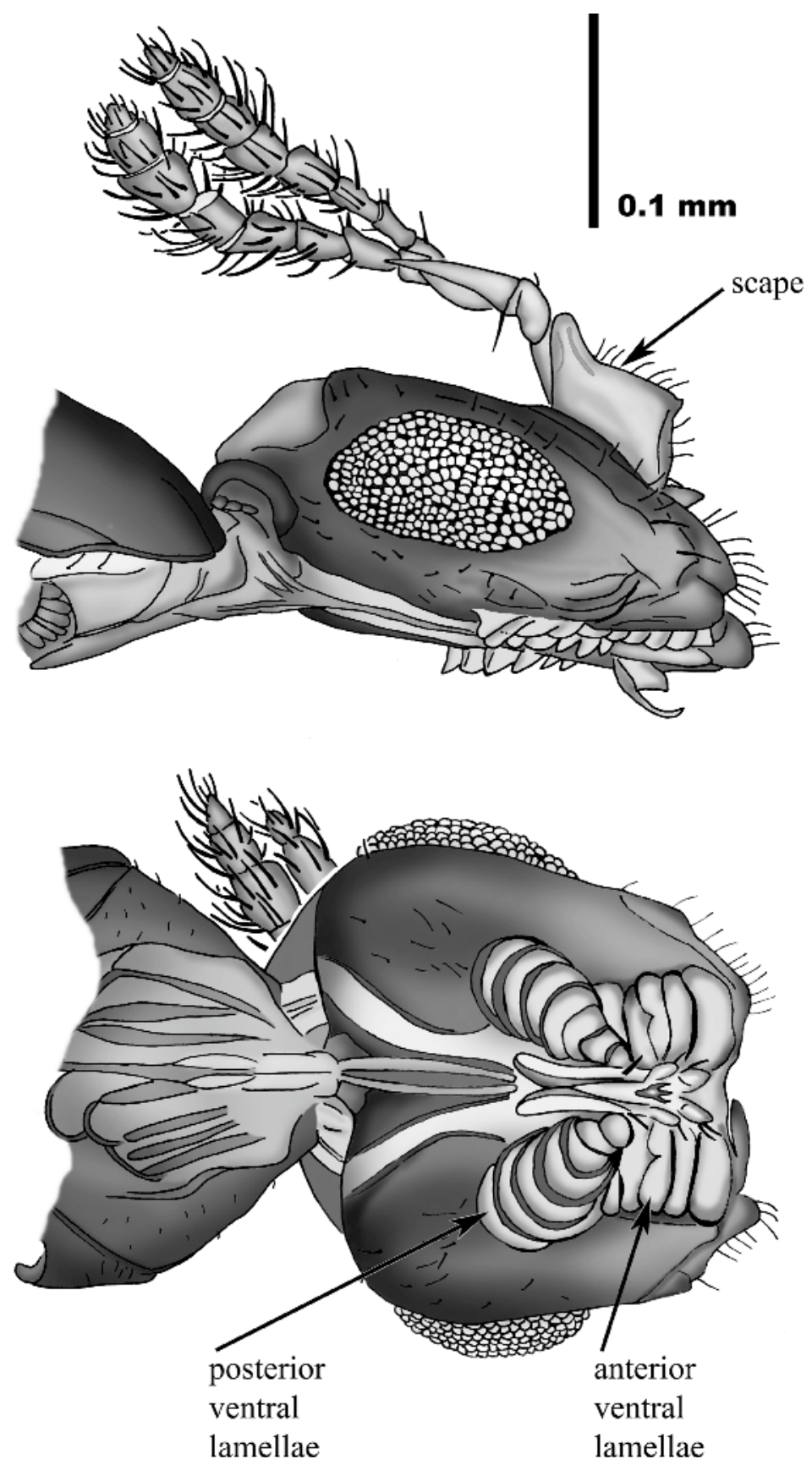

Fig. 8. Camera lucida drawings of the head in lateral and ventral views of the holotype of Pegoscapus peritus Peñalver and Engel, new species (AMNH DR-14-1422).

clusions), AMNH DR-15-82, and AMNH DR-19-368 (agaonid with fig pollen grains and a nematode).
Additional Material: Female, AMNH DR-14-1087b. This specimen is in the same amber piece as paratype AMNH DR-14- 

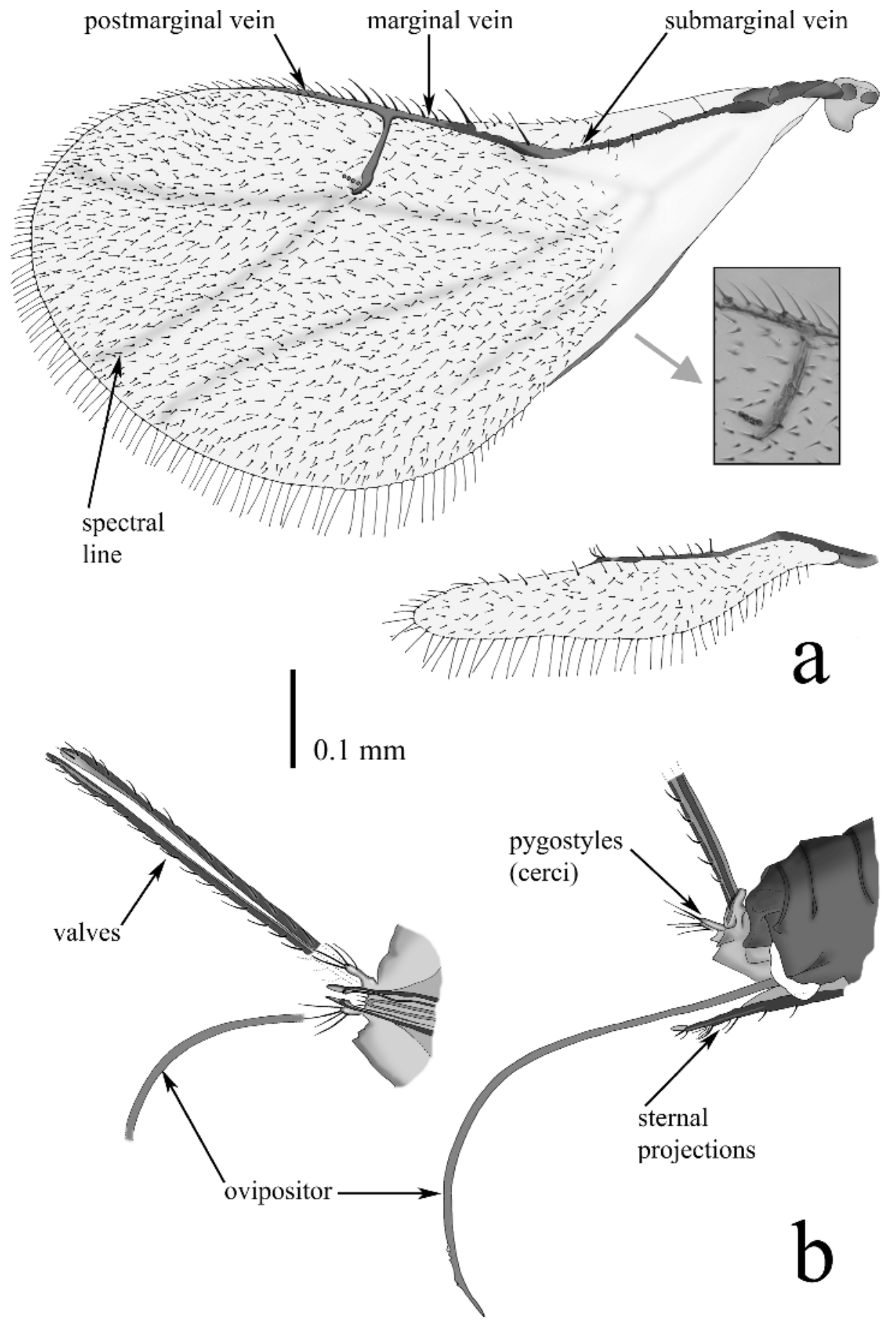

Fig. 9. Camera lucida drawings of the wings and female external genitalia of Pegoscapus peritus Peñalver and Engel, new species. a. Wings and photographic detail of the pterostigma (paratype: AMNH DR-141087a). b. Female external genitalia in ventral (left) and lateral views (right) of the holotype (AMNH DR-141422). All to the same scale. 
1087a (as a syninclusion); however, the specimen is very incomplete, lacking nearly all of the head and half of the mesosoma. As such, we have chosen not to formally designate this secondary specimen as a paratype.

ETYMOLOGY: The specific epithet is the Latin word peritus, meaning "perished".

\section{ACKNOWLEDGMENTS}

We are grateful to Dr. Jesús Selfa and Dr. Torsten Wappler for careful reviews of the manuscript. This research is a contribution from the senior author's (EP) postdoctoral research, "Taphonomy and paleoecology of insects in Dominican amber", supported by a grant from the "Secretaría de Estado de Educación y Universidades" of the Spanish Government and the European Social Fund. Partial support for this work was provided by NSF EF-0341724 and DEB-0542909 (to MSE). This is contribution No. 3455 of the Division of Entomology, University of Kansas Natural History Museum.

\section{REFERENCES}

Brues, C.T. 1910. The parasitic Hymenoptera of the Tertiary of Florissant, Colorado. Bulletin of the Museum of Comparative Zoology 54: 3-125.

Collinson, M.E. 1989. The fossil record of the Moraceae. In: P.R. Crane and S. Blackmore (editors), The evolution, systematics, and fossil history of the Hamamelidae: Volume 2, "Higher" Hamamelidae: 319-339. Oxford: Oxford University Press, xii +356 pp.

Cook, J.M., and J.-Y. Rasplus. 2003. Mutualists with attitude: coevolving fig wasps and figs. Trends in Ecology and Evolution 18(5): 241-248.

Grandi, G. 1919. Contributo alla conoscenza degli Agaonini (Hymenoptera-Chalcididae) dell'America: agaonini di Costa Rica. Bollettino del Laboratorio di Zoologia Generale e Agraria della Rebia Scuola Superiore d'Agricoltura, Portici 13: 15-56.

Grandi, G. 1963. Istituzione di un nuovo sottogenere di Blastophaga Grav. (Hymenoptera Chalcidoidea). Bollettino dell'Istituto di Entomologia della Università degli Studi di Bologna 26: 239-240.

Grimaldi, D. 1995. The age of Dominican amber. In K.B. Anderson and J.C. Crelling (editors), Amber, resinite, and fossil resins: 203-217.
Washington D.C.: American Chemical Society, $\mathrm{xvii}+297 \mathrm{pp}$.

Grimaldi, D., and M.S. Engel. 2005. Evolution of the insects. Cambridge: Cambridge University Press, $x v+755$ pp.

Herre, E.A., C.A. Machado, E. Bermingham, J.D. Nason, D.M. Windsor, S.S. McCafferty, W. Van Houten, and K. Bachmann. 1996. Molecular phylogenies of figs and their pollinator wasps. Journal of Biogeography 23(4): 521-530.

Iturralde-Vinent, M.A., and R.D.E. MacPhee. 1996. Age and paleogeographical origin of Dominican amber. Science 273(5283): 1850-1852.

Jiang, Z.-F., D.-W. Huang, C.-D. Zhu, and W.-Q. Zhen. 2006. New insights into the phylogeny of fig pollinators using Bayesian analyses. Molecular Phylogenetics and Evolution 38(2): 306-315.

Kjellberg, F., E. Jousselin, M. Hossaert-McKey, and J.-Y. Rasplus. 2005. Biology, ecology, and evolution of fig-pollinating wasps (Chalcidoidea, Agaonidae). In C.W. Schaefer and M. Toni (editors), Biology, ecology and evolution of gall-inducing arthropods [vol. 2]: 539-572. Enfield: Science Publishers, xxi + 431-817 pp.

Machado, C.A., E.A. Herre, S. McCafferty, and E. Bermingham. 1996. Molecular phylogenies of fig pollinating and non-pollinating wasps and the implications for the origin and evolution of the fig-fig wasp mutualism. Journal of Biogeography 23(4): 531-542.

Machado, C.A., E. Jousselin, F. Kjellberg, S.G. Compton, and E.A. Herre. 2001. Phylogenetic relationships, historical biogeography and character evolution of fig-pollinating wasps. Proceedings of the Royal Society Biological Sciences, Series B 268(1468): 685-694.

Nascimbene, P., and H. Silverstein. 2000. The preparation of fragile Cretaceous ambers for conservation and study of organismal inclusions. In D. Grimaldi (editor), Studies on fossils in amber, with particular reference to the Cretaceous of New Jersey: 93-102. Leiden: Backhuys, viii +498 pp.

Poinar, G.O., Jr. 1993. Insects in amber. Annual Review of Entomology 46: 145-159.

Poinar, G.O., Jr., and R. Poinar. 1999. The amber forest: a reconstruction of a vanished world Princeton, NJ: Princeton University Press, xviii $+239 \mathrm{pp}$.

Ramírez, W. 1974. Coevolution of Ficus and Agaonidae. Annals of the Missouri Botanical Garden 61(3): 770-780.

Rasplus, J.-Y., C. Kerdelhue, I. Le Clainche, and G. Mondor. 1998. Molecular phylogeny of fig wasps: Agaonidae are not monophyletic. Comptes Rendus de l'Académie des Sciences, Série III, Science de la Vie 321(6): 517-527. 
Rønsted, N., G.D. Weiblen, J.M. Cook, N. Salamin, C.A. Machado, and V. Savolainen. 2005. 60 million years of co-divergence in the fig-wasp symbiosis. Proceedings of the Royal Society Biological Sciences, Series B 272(1581): 2593-2599.

Schiffler, G., C.O. Azevedo, and R. Kawada. 2002. Agaonidae (Hymenoptera, Chalcidoidea) associados a sicônios de Ficus clusiifolia (Moraceae) da restinga de Três Praias, Guarapari, Espírito Santo, Brasil. Boletim do Museu de Biologia Mello Leitão 14: 5-12.
Weiblen, G.D. 2002. How to be a fig wasp. Annual Review of Entomology 47: 299-330.

Wiebes, J.T. 1979. Co-evolution of figs and their insect pollinators. Annual Review of Ecology and Systematics 10: 1-12.

Wiebes, J.T. 1995. The New World Agaoninae (pollinators of figs Koninklijke Nederlandse Akademie van Wetenschappen, Verhandelingen Afdeling Natuurkunde Tweede Reeks, 94: 1-60. Wu, R.J.C. 1997. Secrets of a lost world: Dominican amber and its inclusions. Santo Domingo: Privately published, 222 pp.

Complete lists of all issues of the Novitates and the Bulletin are available at World Wide Web site http://library.amnh.org/pubs. Inquire about ordering printed copies via e-mail from scipubs@amnh.org or via standard mail from: American Museum of Natural History, Library-Scientific Publications, Central Park West at 79th St., New York, NY 10024. TEL: (212) 769-5545. FAX: (212) 769-5009. 